\title{
Guidelines for Planning, Analysis, Design and Stability of Transfer Girders
}

\author{
Mahesh N. Patil ${ }^{1}$, Yogesh N. Sonawane ${ }^{2}$ \\ ${ }^{1}$ Assistant Professor, R. C. Patel Institute of Technology, Shirpur, Maharashtra, India \\ ${ }^{2}$ Assistant Professor, R. C. Patel Institute of Technology, Shirpur, Maharashtra, India
}

\begin{abstract}
Transfer girder plays a very significant role in design of mega and as well as small structures. Some times for architectural purposes buildings are designed without using any column for a very large span. In such case if ordinary beams are provided they can cause failure such as flexural failure. To avoid this problem of construction of some very long span halls etc the concept of deep beams is very effective and durable. Many times when the necessity of transfer girder arises in the cases mentioned above, design engineer has to suffer a lot. Step by step procedure for the design of transfer girder is not available on web or in any text book. Here with the help of this paper an honest effort are taken to give guidelines to the design engineers for Planning, Analysis, Design and Construction of Transfer Girders with the help of strut and tie model.
\end{abstract}

Keywords: planning, analysis, design, stability, transfer girder

\section{Introduction}

In structural engineering, most concrete linear elements are designed by a simplified theory, using the Bernoulli hypothesis. However, the application of this hypothesis to any structural element can lead to over or under sizing of certain parts of the structure. These things are happened particularly in case of transfer girders, as these are heavily loaded deep beams. Thus, for transfer girders the assumptions of Bernoulli hypothesis do not adequately represent the bending structural behavior and the stress distribution. For a real physical analysis about the behavior of these elements the use of the strut-and-tie model, a generalization of the classical analogy of the truss beam model, is customary.

\section{General Arrangement}

Let us take an example of 9 meter depth floor deep girder, the step by step procedure for general arrangement is as shown below.

1. The $9 \mathrm{~m}$ depth of the girder will be divided in three parts. The top and bottom chords will be of $2 \mathrm{~m}$ depth. The Balance $5 \mathrm{~m}$ between the top and bottom chords will be treated as the web of the girder.

2. The bottom chord of the girders to be designed for the slab at the lower level, self weight of the completed girder (full $9 \mathrm{~m}$ depth along with any slabs within the girder depth) and all types of construction loads.

3. The top and bottom chords of $2 \mathrm{~m}$ depth will be cast monolithic, although there may be vertical construction joints. There will be no horizontal layers in the top and bottom chords.

4. There can be any number of joints in the web.

5. In order to decide the geometry of the Strut - Tie model, draw load flow bands from the floating columns to the supports.

6. Openings in the girders will be located avoiding the load flow lines. This is true even in the case of beam models.

7. Try to provide as many openings as possible in the girders. However, restrict the openings to the following sizes. i. Door Opening: 1200 w x 2500 h. The required door height is 2400; however, add $100 \mathrm{~mm}$ on account of floor finishes, giving finished clear opening of 2400. The 100 $\mathrm{mm}$ screed could be used for concealing any cables or accommodating a small drain pipe.

ii. Services Opening A: 600 x 600. To be provided at mid height and in the middle $1 / 3^{\text {rd }}$ span.

iii. Services Opening B: 300 x 300. To be provided near soffit of the ceiling slab.

8. Provide general insert plates in the faces of the girders, soffits of the openings in the girders and the ceilings. These inserts should be general in nature and should be 250 x 250 x $16 \mathrm{~mm}$ typical all throughout. The spacing should be around 2.5 to $3 \mathrm{~m}$. This is as a precaution against undue chipping or drilling of girders for fixing any sort of contraptions at a later date.

9. Additional columns may be floated from top of the girders to support the service slab and the first apartment level, if it helps availing more headroom for services.

10. The service floor and the first living level framing may be different from the typical floors on account of column sizes and additional columns floated from the top of the girders.

11. Tie beams shall be provided at the root of the floating column in direction perpendicular to the length of the girder.

\section{Co-ordination}

Actual Plan, Section and Elevation details shall be prepared to arrange reinforcement in the girders. The co-ordination shall be made as follows;

- Sub-girder column reinforcement

- Floating column reinforcement

- Cross girder reinforcement

- PT tendons

- PT stressing blocks and dead anchors

- Damper inserts

- Openings in the girders

- Cross beam reinforcement 


\section{International Journal of Science and Research (IJSR) \\ ISSN (Online): 2319-7064 \\ Index Copernicus Value (2013): 6.14 | Impact Factor (2014): 5.611}

- Elevation fins and parapet reinforcement

- Services inserts

- Precautionary inserts

- It is proposed to erect a mock up of one of the girders, which will provide preconstruction experience of coordination of all the above points.

\section{Analysis}

Consider following procedure for step by step analysis

1. The effective span of the girders will be assumed as the clear span $+1.2 \mathrm{~m}+1.2 \mathrm{~m}$

2. The effective depth for calculations of reinforcement shall be assumed as overall depth of the girder $-1.0 \mathrm{~m}$

3. Try to model the eccentricity of the floating columns on the girders to assess the torsional effects in the SFEM model.

4. The girders will be designed by one of the four methods. Different girders may be designed with different method. The methods are as follows :

i. Deep Beam: Simply supported and continuous over internal supports.

ii. Deep Beam: Fixed end beam and continuous over internal supports.

iii. Strut and tie: For all girders with span / depth ratio more than 2, this method will not be used. In this method, there will be following three models.

- Rectangular truss with Top and bottom chords and diagonal load flow bands.

- Corner members at the top to be deleted from the above model No.1.

- Delete bottom chord from Model No.2

\section{Solid Finite Element Method (SFEM)}

a. For all the girders, the design will be finally verified by analyzing a Solid Finite Element Model. This approach will be mandatory. In the SFEM, the columns will be modeled at the supports for a height of $4.2 \mathrm{~m}$, meshed equally. The element size will be $1.2 \mathrm{~m} \times 1.2 \mathrm{~m} \times 1.2 \mathrm{~m}$ for $1.2 \mathrm{~m}$ wide girders and $1.5 \times 1.5 \times 1.5 \mathrm{~m}$ for $1.5 \mathrm{~m}$ wide girders (or integer divisions thereof).

b. Load on the SFEM model will be applied in the form of pressure on the surface of the solid element. The total load will be distributed over the entire $1.2 \mathrm{~m} \times 1.2 \mathrm{~m}$ surface area if the bearing area is lesser than $1.2 \times 1.2 \mathrm{~m}$. For this purpose, in reality, pedestals will be built on top of the girder, from the top of which the actual column size will be sprung.

c. Moment reaction of the floating column will be applied as a pressure couple on the top of the girder. The pressures on the extreme elements directly under the column will be calculated by dividing the moment by the distance between the centres of the extreme elements under the cross sections of the column. The direction of the pressures will be opposite - i.e. on one element, the pressure will be positive and on the other, it will be negative.

d. For cantilever girder in SFEM model, provide pinned supports at the face of the girder where tie beams rest on girder top and girder bottom levels. e. In SFEM model, the load of secondary girders should be distributed throughout the height of the primary girder at their junction, as this load will not act only at the top element surface. However, the load of the floating column will act only on the top surface of the top girder.

f. In SFEM model, provide pinned supports throughout the height of the girder to secondary girder when it rests on the main girder.

g. In SFEM model, models will have to be analyzed as assembly of girders resting on each other, ultimately transferring the loads to the sub-girder columns.

\section{SFEM STAAD. Pro Models}

Examples of SFEM models, generated on STAAD Pro are as shown below;

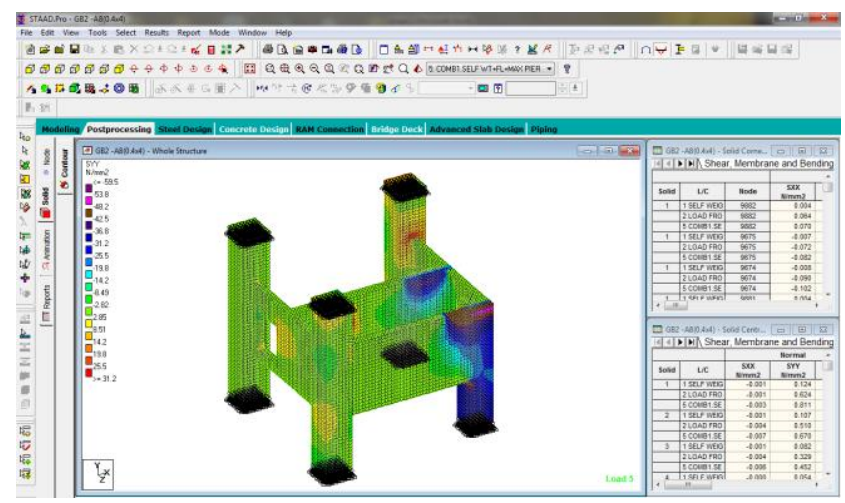

Figure 1: Model for assembly of transfer girder.

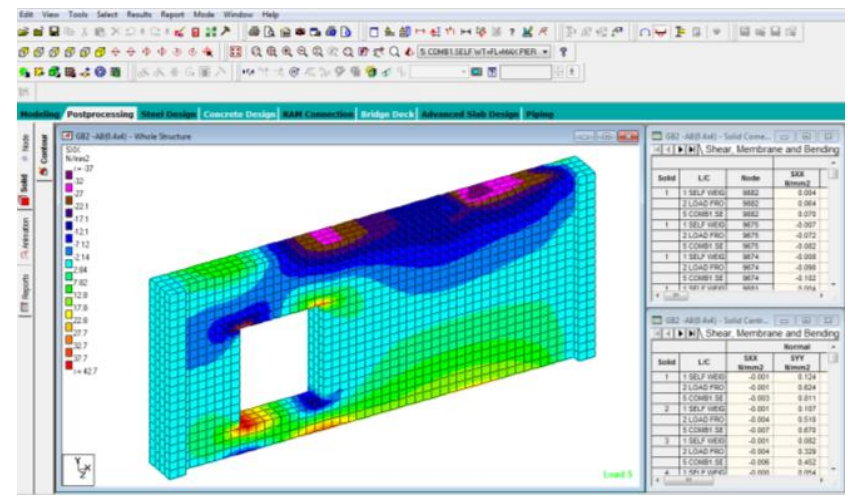

Figure 2: Model for design of transfer girder with opening.

\section{Design Procedure of Transfer Girder}

\section{i. Deep Beam: Simply supported}

1. Check each beam for its adherence to Clause 29.1 of IS 456:2000.

2. Calculate reinforcement on the basis of the Lever Arm calculations as per Clause 29.2 of IS 456:2000.

3. Shear force is deemed to be satisfied. However, provide nominal reinforcement as per formula in Clause 26.5.1.6 of IS 456 for nominal shear reinforcement in beams.

\section{ii. Deep Beam: Fixed End.}

1. Check each beam for its adherence to Clause 29.1 of IS 456:2000. 


\section{International Journal of Science and Research (IJSR) \\ ISSN (Online): 2319-7064 \\ Index Copernicus Value (2013): 6.14 | Impact Factor (2014): 5.611}

2. Calculate reinforcement on the basis of the Lever Arm calculations as per Clause 29.2 of IS 456:2000.

3. Reinforcement calculated for tension - whether in the top chord or in the bottom chord - shall be continued throughout the length of all the continuous spans, i.e. from one extreme end support to the other extreme end support of the set of the all consecutive continuous beams.

4. Shear force is deemed to be satisfied. However, provide nominal reinforcement as per formula in Clause 26.5.1.6 of IS 456:2000 for nominal shear reinforcement in beams.

\section{iii. Strut and Tie.}

1. For calculating the reinforcement in the struts and ties, adopt the formulae given in the SFEM model design procedure for top and bottom chords for the compression and tension members.

2. Other checks for shear and deep beam verification are as per beam models.

\section{iv, SFEM Model :}

1. Tension reinforcement shall be calculated from the average $\mathbf{S}_{\mathbf{X X}}$ stress of the appropriate number of layers of elements representing the top or bottom chords by the following formula.

$$
A_{S t}=\frac{S_{x x} \cdot n \cdot A_{S E}}{0.66 F_{y}}
$$

Where,

$\mathbf{S}_{\mathbf{X X}}=$ Average of solid element centre stresses for the $\mathrm{n}$ no. elements representing top and bottom chord.

$\mathbf{n}=$ Number of elements representing the top or bottom chord.

$\mathbf{A}_{\mathrm{SE}}=$ Surface Area of the Solid Element on which $\mathrm{S}_{\mathrm{XX}}$ is measured.

$\mathbf{F}_{\mathbf{y}}=$ Yield Stress of reinforcing steel.

2. Reinforcement in compression zone shall be calculated from the following formula.

$A_{s t}=\frac{\left(S_{x x} \cdot n \cdot A_{S E}\right)-\left(0.4 F_{c u} \cdot A_{S E} \cdot n\right)}{0.67 F_{y}}$

Where,

$\mathbf{S}_{\mathbf{X X}}=$ Average of solid element centre stresses for the $\mathrm{n}$ no. elements representing top and bottom chord.

$\mathbf{n}=$ Number of elements representing the top or bottom chord.

$\mathbf{A}_{\mathrm{SE}}=$ Surface Area of the Solid Element on which $\mathrm{S}_{\mathrm{XX}}$ is measured.

$\mathbf{F}_{\mathbf{y}}=$ Yield Stress of reinforcing steel.

$\mathbf{F}_{\mathbf{c u}}=$ Characteristic strength of concrete.

3. Wherever provided reinforcement as per the accommodative capacity of the top or bottom chord experiencing tension is inadequate, calculate the unbalanced tensile force to be resisted in terms of the number of reinforcing bars required. The un-balanced tensile force in the top or bottom chord shall be compensated by applying an equivalent compression to the respective chord by Post-Tensioning the chord. For the purpose of applying the Post Tension, a 27 strand cable of $12.7 \mathrm{~mm}$ wires shall be used. Write the Post Tension force on each girder profile drawing.

4. Reinforcement in load flow band - the strut joining the point loads to the supports - shall be calculated on the basis of the principle stresses or $\mathbf{S}_{\mathbf{x y}}$. The maximum width of the strut shall be $1 / 3^{\text {rd }}$ of the horizontal distance between the column support (1.2 $\mathrm{m}$ inside the column face) and the centre of the column / cross girder acting as the point load. In case the compressive stress in the strut is less than $0.4 \mathrm{x}$ fck, i.e. $24 \mathrm{~N} / \mathrm{mm}^{2}$, no additional diagonal reinforcement is necessary. If the stress exceeds this value, additional reinforcement shall be provided corresponding to the (balance compressive stress $\mathrm{x}$ cross sectional area of the strut) in the strut within the width as mentioned above. The diagonal reinforcement shall be arranged as if it is an inclined column, with column links detailed as per IS 456:2000.

5. Appropriate load transfer reinforcement in the form of horizontal reinforcement in the top chord shall be provided in view of the impossibility of the diagonal reinforcement to enter into the junction of the pedestal and the top chord reinforcements. Where the strut reinforcement enters the column support, some adjustment of vertical column bars may be considered depending on the site situation.

\section{Stability and Strength Check}

1. Calculate the minimum number of column bars required corresponding to the forces just below girder bottom from Etabs analysis. Be prepared to cut the extra column bars if they are obstructing laying of girder bars. Remember, the column bar layout on the site will not be accurate as shown in our drawings.

2. In case of multiple floating columns and continuous girders, check tensile forces on the top chord.

3. Check for bearing stress at the root of the floating columns and at the junctions of the sub-girder columns and the girders.

4. Vertical deflections of all column roots to be examined for differential settlements of the super-structure columns. Tabulate the deflections to design the first set of floors with sinking supports. There will be bottom reinforcement in the beams over the column supports to take care of induced positive moments at the supports.

5. Deflection values of the girders to be conveyed to PT vendor for ascertaining tendon forces.

6. Crack width of the tie shall be checked as per ACI 10.6.4 and RA.4.2

7. Check possibility of vertical splitting at the bearing area of the junction of the floated column and the girder / pedestal. Horizontal reinforcement perpendicular to the sides of the girders may be provided. 


\section{References}

[1] Wight, J.K., and Parra-Montesinos, G. "Strut-and-tie model for deep beam design“, ACI Concrete International, Vol. 25, No. 5, 2003, pp. 63-70

[2] Wight, J.K. Keynote "Development of the Strut-and-Tie Method for Appendix A of the Building Code (ACI 31808)", 2008.

[3] V. Almeida, "The strut-and-tie models in reinforced concrete structures analyzed by a numerical technique", IBRACON STRUCTURES AND MATERIALS Journal, Volume 6, Number 1 (February 2013) pp. 139-157 • ISSN 1983-4195.

[4] Indian Standard Code of Practice Plain and Reinforced Concrete $^{e e}$ IS 456:2000-. Bureau of Indian Standards, Manak Bhavan, New Delhi, India.

[5] Appendix A of Aci-318 American Concrete Institute (Building Code Requirement for Structural Concrete ACI -318-2005 and Commentary ACI- 318r-2005).

[6] AASHTO, "AASHTO LRFD Bridge Specifications for Highway Bridges" (2001 Interim Revisions), American Association of Highway and Transportation Officials, Washington, D.C., 1998.

[7] "British code of practice", B.S.8110-02(BRITISH STANDARD Structural Use of concrete part-1 Code of practice for design and construction)

[8] Varghese P.C., "Advanced Reinforced Concrete Design"e, Prentice Hall of India Pvt. Ltd. New Delhi.

[9] Varghese and Krishnamurthy, „Strength and Behavior of Deep Reinforced Concrete Beams ${ }^{\text {ee }}$ Indian Concrete Journal, 104-108, March 1966.

[10] Nagarajan P, Dr Pillai M M T and Dr Ganesan N, "Design of simply supported Deep Beam using IS 456: 2000 and Strut and Tie Method", IE (I) Journal-CV Vol.88 38-43, May 2007.

\section{Author Profile}

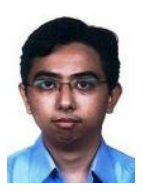

Mahesh N. Patil received the B.E. degree in Civil Engineering from North Maharashtra University in 2006 and M.Tech degree in Structural Engineering from SVNIT, Surat in 2010. Now he is working as Assistant Professor at R. C. Patel Institute of Technology, Shirpur.

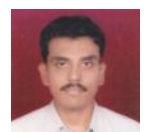

Yogesh N. Sonawane received the B.E. degree in Civil Engineering from North Maharashtra University in 2008 and M.Tech degree in Structural Engineering from SVNIT, Surat in 2010. Now he is working as Assistant Professor at R. C. Patel Institute of Technology, Shirpur. 